\title{
SCNS. 16. Detection of antidepressant activity of Riparin III through behavioral tests
}

\author{
VASCONCELOS,A.S.,OLIVEIRA,I.C.M.,CAPIBARIBE,V.C.C.,RODRIGUES,F.A.P., \\ SOUSA, F.C.F. \\ *irisbusy@yahoo.com.br
}

Introduction: Depression affects approximately $17 \%$ of people in the world resulting in enormous personal suffering and economic burden. Despite the advances of antidepressants, the development of new drugs with better efficacy with reduced latency and therapeutic effect of relapses and fewer side effects is needed. Therefore, the search for new drugs based on natural products has grown. The substance named Riparin III (Rip III) has been isolated from an alcamide of the Aniba riparia showing antidepressant effects in preclinical models. Objectives: The aim of this study was to investigate the activity of Rip III in mice submitted to a model of depression induced by corticosterone administration. (CORT). Methods: Swiss female mice were used weighing between 25-30g, divided according to the following experimental groups: controls (vehicle - saline, 1\% Tween80, 1\% DMSO , sc , for 14 and 21 days in a row), Group with Stress (CORT, 20mg/kg sc for 14 or 21 days), a group treated with Riplll (50 mg/kg, ov for 7 days) group treated with fluvoxamine (Flu) $\left(50 \mathrm{mg} / \mathrm{kg}\right.$, ov for 7 days). Treatments were performed after the $14^{\text {th }}$ day of corticosterone-induced stress. Depression was induced by repeated injections of CORT (20 mg kg, sc) over 14 days. Behavioral models were evaluated: Forced Swim (FS) and Tail Suspension (TS). The group treated with CORT showed a higher time of immobility (TI) in FS and TS tests compared to controls (TS: Cont.: $45 \pm 7.30$; CONT.: $108.9 \pm 3.5$; $p$ < 0.01). While the groups treated with RipllI (50) and Flu (50), presented a smaller $\mathrm{TI}$

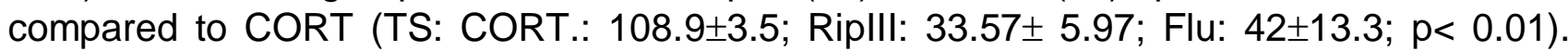
Conclusions: The depressive behavior was triggered by the administration of CORT and reversed by treatment with RiplII and Flu. The results suggest that Rip III triggers a possible antidepressant effect that deserves further investigation.

Funding: CNPq, CAPES, FUNCAP

VASCONCELOS, A.S.; OLIVEIRA, I.C.M.; CAPIBARIBE, V.C.C.; RODRIGUES,F.A.P.; SOUSA, F.C.F. 2013. Detection of antidepressant activity of Riparin III through behavioral tests, p.26. In: Oriá, Reinaldo Barreto; Andrade, Geanne Matos de; Bruin, Veralice Meireles S. de. I International Symposium in Neuroscience Meeting [Blucher Neuroscience Proceedings n.1 v.1]. São Paulo: Blucher, 2014 http://dx.doi.org/10.5151/isnm-sine21

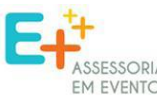

